ORIGINAL RESEARCH PAPER

\title{
QUALITY PARAMETERS, PROBIOTIC VIABILITY AND SENSORY PROPERTIES OF PROBIOTIC STIRRED SESAME YOGURT
}

\author{
RADIA ARAB ${ }^{1}$, M. LAMINE FREIDJA ${ }^{1,2}$, B. DAVE OOMAH ${ }^{3}$, SONIA BENALI $^{1,4}$, KHODIR $^{*}$ \\ MADANI $^{1,5}$, LILA BOULEKBACHE- MAKHLOUF ${ }^{1 *}$ \\ ${ }^{1}$ Laboratoire de Biomathématiques, Biophysique, Biochimie, et Scientométrie (L3BS), Faculté des Sciences de la \\ Nature et de la Vie, Université de Bejaia, 06000 Bejaia, Algérie \\ ${ }^{2}$ Department of Biochemistry and Microbiology, Faculty of Sciences,University of M'sila, 28000 M'sila, Algeria \\ ${ }^{3}$ Formerly with Summerland Research and Development Centre, Agriculture and Agri-Food Canada, Summerland, \\ BC, V0H 1Z0, Canada \\ ${ }^{4}$ Faculté des Sciences de la Nature et de la Vie, Université de Jijel, 18000 Jijel, Algeria \\ ${ }^{5}$ Centre de recherche en technologie agro-alimentaire, Route de targua-ouzemour, 06000, Bejaia, Algérie \\ *Corresponding author: lilaboulekbachemakhlouf@yahoo.fr
}

Received on 19 March 2020

Accepted on 16 June 2020

\begin{abstract}
The beneficial effects of sesame seeds are of great interest for the conception of healthy dairy products such as probiotic stirred yogurt. We investigated the effects of adding raw or roasted sesame seeds on the probiotic viability, quality parameters and consumers acceptability of stirred yogurt during 28 days cold storage $\left(4{ }^{\circ} \mathrm{C}\right)$. All yogurts were analyzed for microbial counts (starter culture and probiotic), $\mathrm{pH}$, titratable acidity, proteolytic activity, syneresis and antioxidant activity. Yogurts containing sesame seeds showed the highest probiotic counts, proteolytic activity, radical scavenging activity high titratable acidity, and low $\mathrm{pH}$. Raw and roasted sesame can selectively impact probiotic growth with limited effect on yogurt starter culture especially at long cold storage (14-28 days). Yogurts enriched with roasted sesame had higher sensory acceptability compared to control and probiotic yogurts. Roasted sesame can be successfully incorporated to improve probiotic viability and sensory properties of stirred yoghurt, as well as to improve the antioxidant properties.
\end{abstract}

Keywords: probiotic, sesame yogurt, sensory evaluation, fermentation, proteolytic activity, antioxidant capacity

\section{Introduction}

In recent years, consumers around the world are very interested in foods that provide positive health benefits. This social phenomenon is certainly linked to increased awareness of the link between food quality and health. Yogurt is the most known and consumed fermented milk with high nutritional value and health

https://doi.org/10.35219/foodtechnology.2020.1.01 
promoting ingredients (Allgeyer et al., 2010). It is coagulated milk made by lactic fermentation without drainage with two symbiotic and homofermentative cultures: Streptococcus thermophilus and Lactobacillus delbrueckii subsp. Bulgaricus (Shah, 2007; Sodini et al., 2004). Consumption of yogurt helps improve diet quality because it is an excellent source of protein, vitamin B2 and B12, folate, niacin, calcium, magnesium, phosphorus and zinc (Mckinley, 2005). Yogurt is also a rich source of bioactive peptides released during lactic fermentation by lactic acid bacteria (Akalın et al., 2012). In addition, it can be consumed by people with lactose intolerance, due to the modification of allergenic properties of milk (Bernat et al., 2015; Viljoen, 2001). The increase in per capita annual consumption of yogurt can be attributed to the diversification (probiotic or symbiotic yogurt, light or defatted yogurt, fruit yogurt and liquid yogurt drinks) and availability of the low priced product in the market. Probiotics have experienced a renewed interest actually, marked by an explosion of scientific publications/papers underpinned by the partnership with the agri-food industry. The publications are based on Élie Metchnikoff theory, who proposed that the acid-producing organisms in fermented dairy products can prevent "fouling" in the large intestine and thus prolong the consumer's life span (Anukam and Reid, 2007; Heller, 2001). Probiotics exert several health benefits, including improving lactose digestion, immune and gastrointestinal system (Hatcher and Lambrecht, 1993; Plessas et al., 2012), restoring microbial balance in the host gut flora (Gibson and Roberfroid, 1995), preventing cancers (Reddy et al., 1983), lowering cholesterol (Gilliland and Walker, 1990) and enhancing protection against pathogenic bacteria using three types of biological processes: immunomodulation; direct antimicrobial activity and reinforcement of the epithelium barrier function (Alexandre et al., 2014). Among the probiotic strains, $B$. animalis subsp. lactis (Bb12) is the most studied and documented in the literature with over 200 scientific publications (Garrigues et al., 2010). It can withstand harsh conditions compared to other strains and hence its common use in probiotic foods. It can survive passage through the gastrointestinal tract with high capacity to adhere to enterocytes (Haschke et al., 1998), it is also a technologically suitable strain because without adversely affecting taste and texture of food products (Moller and De Vrese, 2004). The viable count of each probiotic bacteria is very important to provide health benefits to the host. Consumption of probiotic yogurt over $100 \mathrm{~g}$ per day is generally recommended (Rybka and Kailasapathy, 1995) and the minimum viable counts of each probiotic strain must be $106 \mathrm{cfu} / \mathrm{mL}$ (Tamime et al., 2005).

Sesame (Sesamum indicum L.) is the first cultivated oilseeds by humans and one of the world's most important crops (Uzun et al., 2007). It has long been considered a healthy food providing energy and preventing aging in the orient (Halvorsen et al., 2002). Sesame seeds are a potential source of nutrients, containing $35-57 \%$ oil, 20 $25 \%$ protein, $20-25 \%$ carbohydrate and 5-6\% ash (Salunke et al., 1992). Seeds are a rich source of beneficial bioactive compounds and endogenous antioxidants mainly phenolic lignans (sesamol, sesamolin, sesamin and sesamino-lglucosides) (Bedigian, 2004; Uzun et al., 2007), tocopherols and phytosterols (Bae et al., 2016). Regular consumption of sesame seeds helps to low cholesterol (maintain 
HDL and lower LDL) and blood pressure and protects the liver from oxidative damage due to the presence of sesamin and sesamolin (Anilakumar et al., 2010). Actually, much attention has been directed toward the utilization of oilseed for dairy manufacture including dairy drinks and vegetable milks (soy, almond and sesame milk). The major uses of sesame in human food are: oil production, Tahina and Halawa manufacture and garnish of bakery products (Kinsella et al., 1985).

Sesame has previously been incorporated in fermented dairy products, but the seed was unroasted. Raw sesame seeds increased titratable acidity, protein and fat content, amino acids especially some essential amino acids and omega fatty acids. Bacterial counts of sesame enriched yogurt increased and the best sensory scores was obtained with $2 \%$ sesame supplementation (Aziz and Aboeleinen, 2010).

Due to the huge popularity of yogurt among consumers, producers and manufacturers continue to develop new yogurt assortments with value-added ingredients. Nutraceutical functions and positive effects of sesame seeds were previously reported (Namiki, 2007). It is important to combine the nutritional value of sesame and the health benefits of probiotic culture in yogurt. Our study (i) evaluated the effects of ground raw and roasted sesame on stirred yogurt quality parameters $(\mathrm{pH}$, titratable acidity and syneresis) and probiotic growth, (ii) determined the acceptability of sesame yogurt by consumers comparing between roasted and unroasted sesame yogurts.

\section{Materials and methods Material and microbial cultures}

White sesame seeds (Sesamum indicum) imported from India were purchased from a local market in Bejaia (Algeria). Impurities such as dust, sand, stones, spoiled seeds and other extra materials were sieved through a $5 \mathrm{~mm}$ screen. One part of the seeds was roasted at $180^{\circ} \mathrm{C}$ for 20 minutes using an electric oven. Roasted and unroasted seeds were ground (GM 200; Retsch GmbH, Germany) to achieve particle size of 2-3 mm then stored in sealed plastic bags $\left(4^{\circ} \mathrm{C}\right)$ until use to avoid oxidation.

The freeze-dried mixture of starter cultures (Lactobacillus delbrueckii ssp. bulgaricus and Streptococcus salivarus ssp. thermophilus) and the probiotic strain (Bifidobacterium animalis ssp. lactis, BB-12) were purchased from CHR Hansen (France).

\section{Determination of optimum sesame incorporation}

Pasteurized milk was mixed with skim milk powder to have milk with $18 \%$ total solids and stirred at $85{ }^{\circ} \mathrm{C}$ for $20 \mathrm{~min}$. After cooling to $40{ }^{\circ} \mathrm{C}$, the starter culture was incorporated and the milk was divided into conical tubes $(50 \mathrm{~mL})$. Variable concentrations of ground sesame seeds $(0-10 \%, w / v)$ were added in order to determine the best incorporation rate that can be added to milk before fermentation without producing syneresis and disrupting bacterial growth (Agil et al., 2013). Incubation was carried out at $40-42^{\circ} \mathrm{C}$ until $\mathrm{pH} 4.5$. 


\section{Yogurt manufacture}

Yogurt was prepared in a laboratory scale using the method described previously (Kailasapathy et al., 2008). Pasteurized milk (3.5\% fat) was purchased locally from a commercial source (Candia, Bejaia). Skim milk powder (SMP) was added with speed stirring, to have milk with $18 \mathrm{~g} / 100 \mathrm{~g}$ total solids. Then it was heated to 85 ${ }^{\circ} \mathrm{C}$ for $20 \mathrm{~min}$ and cooled quickly to $40{ }^{\circ} \mathrm{C}$. Commercial sugar $(8 \%)$ and $2 \mathrm{~g} / 100 \mathrm{~g}$ $(\mathrm{w} / \mathrm{w})$ of frozen yogurt starter culture was incorporated and the mixture stirred continuously then divided in $150 \mathrm{~mL}$ plastic yogurt cups. Freeze-dried culture of $B$. animalis ssp. Lactis $\left(10^{8} \mathrm{cfu} / \mathrm{g}\right) 2 \mathrm{~g} / 100 \mathrm{~g}(\mathrm{w} / \mathrm{w})$ was incorporated and sesame seeds (6\%) added to make six yogurts: Y, YP, YUS, YRS, YPUS, and YPRS (Table 1).

Table 1. Formulation of standard or control yogurt (Y), probiotic yogurt (YP), unroasted sesame yogurt (YUS), roasted sesame yogurt (YRS), probiotic unroasted sesame yogurt (YPUS) and probiotic roasted sesame yogurt (YPRS).

\begin{tabular}{cccccc}
\hline Samples & $\begin{array}{c}\text { Total } \\
\text { solid\% }\end{array}$ & $\begin{array}{c}\text { Lactic ferment } \\
\mathbf{\%}\end{array}$ & $\begin{array}{c}\text { Sugar } \\
\mathbf{\%}\end{array}$ & $\begin{array}{c}\text { Probiotic } \\
\mathbf{\%}\end{array}$ & $\begin{array}{c}\text { Sesame seed } \\
\mathbf{\%}\end{array}$ \\
\hline Y & 18 & 2 & 8 & 0 & 0 \\
YP & 18 & 2 & 8 & 2 & 0 \\
YUS & 18 & 2 & 8 & 0 & 6 \\
YRS & 18 & 2 & 8 & 0 & 6 \\
YPUS & 18 & 2 & 8 & 2 & 6 \\
YPRS & 18 & 2 & 8 & 2 & 6 \\
\hline
\end{tabular}

Incubation was carried out at $40-42{ }^{\circ} \mathrm{C}$ until a $\mathrm{pH}$ of 4.5. After fermentation yogurts were quickly cooled in ice water bath then stirred. Samples were prepared in triplicate and the yogurt cups were sealed then stored in the refrigerator at $4{ }^{\circ} \mathrm{C}$ for 28 days for analysis.

\section{Enumeration of probiotic and starter cultures}

Bacterial count was carried out weekly for a total of four weeks (days 1, 7, 14, 21, and 28). For each lot at different dilutions (four to five serial dilution of 1/10), $100 \mu \mathrm{L}$ of each of the last three dilutions were spread by the streaks method on Petri dishes. For enumeration of starter cultures, the inoculated media were incubated at $40{ }^{\circ} \mathrm{C}$ for $24 \mathrm{~h}$ (Espírito Santo et al., 2010). The probiotic was enumerated on MRS agar containing L-cysteine hydrochloride $(0.5 \mathrm{~g} / \mathrm{L})$ and incubated $\left(40^{\circ} \mathrm{C}, 72 \mathrm{~h}\right)$ under anaerobic conditions (Rodrigues et al., 2012). Plates containing 30-300 colonies were enumerated and the results were expressed as log colony forming units per milliliter $(\log \mathrm{cfu} / \mathrm{mL})$ using the equation 1(Sun-Waterhouse et al., 2013):

$$
\mathrm{cfu}=\text { number of colonies/plate factor } \mathrm{x} \text { dilution factor }
$$

where the plate and dilution factors refer to the amount of sample pipetted and the dilution series of the yogurt sample, respectively.

\section{Determination of $\mathrm{pH}$ and total titratable acidity (TTA)}

$\mathrm{pH}$ was measured at $25^{\circ} \mathrm{C}$ by electrode immersion with a $\mathrm{pH}$ meter (211 HANNA) each week until the $28^{\text {th }}$ day. Yogurt $(1 \mathrm{~mL})$ was mixed with distilled water $(9 \mathrm{~mL})$ 
with a few drops (3 to 5) of phenolphthalein $0.1 \%(\mathrm{w} / \mathrm{v})$. The titration was made with a solution of $\mathrm{NaOH}(0.1 \mathrm{~N})$ until the persistence of a pink color. The volume of $\mathrm{NaOH}$ used for titration was noted and the titratable acidity (TTA \%) was expressed as a percentage lactic acid equivalent and calculated according to equation 2:

$$
\text { TTA }(\%)=\mathrm{V}_{\mathrm{NaOH}} \times 0.1 \mathrm{~N} \times 100 \% \times 0.009 \times 10
$$

where: $\mathrm{V}_{\mathrm{NaOH}}-$ Volume of $\mathrm{NaOH}$ in $\mathrm{mL}$ used for titration; 0.0090 - coefficient corresponding to lactic acid; 10 - dilution factor.

\section{Proteolytic activity}

To measure proteolysis of yogurt bacteria during cold storage, the $O$ phthaldialdehyde (OPA) method was used (Donkor et al., 2007). The concentration of free amino groups and peptides is proportional to the absorbance at $340 \mathrm{~nm}$.

\section{Syneresis}

Syneresis was determined using the centrifugation method (Aprianita et al., 2009).Yogurt $(10 \mathrm{~g})$ from different days storage was centrifuged (Bench-top centrifuge NF 200 , Belgium) $700 \times \mathrm{g}$ at $8{ }^{\circ} \mathrm{C}$ for $10 \mathrm{~min}$. The clear supernatant was weighed, and syneresis was expressed as percent weight of supernatant relative to the original yogurt weight using equation 3 :

$$
\text { Syneresis }(\%)=(\text { weight } \text { of collected whey/weight of yogurt }) \times 100
$$

\section{Antioxidant activity by DPPH inhibition assay}

First, water yogurt extracts were prepared using the method of (Amirdivani and Baba, 2011). Yogurt (10 g) was mixed with $2.5 \mathrm{~mL}$ of distilled water; the mixture was stirred, and adjusted to $\mathrm{pH} 4$ with $\mathrm{HCl}$ solution $(0.1 \mathrm{M})$. The mixture was heated in a water bath $\left(45^{\circ} \mathrm{C}, 10 \mathrm{~min}\right)$ and centrifuged $\left(5000 \mathrm{~g}, 10 \mathrm{~min}, 4^{\circ} \mathrm{C}\right)$ to remove precipitated proteins. The supernatant was adjusted to $\mathrm{pH} 7$ with $0.1 \mathrm{M}$ $\mathrm{NaOH}$ and centrifuged $(5000 \mathrm{~g}, 10 \mathrm{~min})$ to remove residual proteins and salts then stored at $-20^{\circ} \mathrm{C}$ for later use. Extractions were carried out in triplicates.

The antioxidant capacity of yogurt extracts was determined as described previously (Behrad et al., 2009). Yogurt water extract $(250 \mu \mathrm{L})$ was mixed with ethanol solution of $60 \mu \mathrm{M}$ DPPH $(3 \mathrm{~mL})$. The mixture was shaken vigorously and then incubated for $20 \mathrm{~min}$ at room temperature in the dark. The absorbance was measured at $517 \mathrm{~nm}$. The readings were compared with the control which contained distilled water instead of yogurt extract. The \% inhibition of DPPH was determined using equation 4 :

$$
\% \text { inhibition }=\left(\mathrm{A}_{\text {control }}-\mathrm{A}_{\text {sample }}\right) / \mathrm{A}_{\text {control }} \times 100
$$

\section{Yogurts sensory evaluation}

Ten untrained panelists familiar with yogurt (students in food sciences and technology from the University of Bejaia, Algeria) were selected for sensory evaluation. The sensory analysis was based on a nine-point 1 (poor) to 9 (excellent) hedonic scales for some sensory parameters including color, odor 
(flavor), taste, texture, acidity, syneresis and overall acceptability (Haque and $\mathrm{Ji}$, 2003). The stored yogurt samples were evaluated by nonsmoker's panel members on the first day of storage. Water and bread were provided between samples to cleanse the palates.

\section{Data analysis}

Three determinations were made for all the assays. Analysis of variance was performed by the general linear models (GLM) procedure, means comparison by Duncan's test, and Pearson correlation according to Statistical Analysis System, SAS 9.1 for Windows.

\section{Results and discussion}

\section{Optimum sesame incorporation}

Yogurts prepared with an incorporation rate of $8 \%$ and $10 \%$ have a liquid consistency and texture like a yogurt drink which is due to the phenomenon of syneresis, this will not be accepted by consumers, but yogurts containing 0 to $6 \%$ of ground sesame have a consistent texture. Consequently, the best concentration was $6 \%$ of ground sesame which can be incorporated into yogurt before fermentation under our experimental conditions without whey separation from gel.

\section{Bacterial counts}

Figure 1a shows the variations in bacterial counts of starter culture in the six yogurts. Bacterial count was affected by sesame supplementation $(P<0.05)$, probiotic $(P<0.0001)$, storage time $(P<0.01)$ and their interaction $(P<0.001)$. Sesame and probiotic exerted beneficial effects on the control yogurt (Y) culture $(P<0.05)$. On the first day of cold storage, S. thermophilus and L. bulgaricus counts did not differ and varied from 8.12 to $8.39 \log \mathrm{cfu} / \mathrm{mL}$; then it declined to $7.45-8.35 \log \mathrm{cfu} / \mathrm{mL}$. Reduction rates varied from 0.47 to $8.28 \%$ in the following order: $\mathrm{Y}>\mathrm{YUS}>\mathrm{YRS}>\mathrm{YPRS}>\mathrm{YPUS}>\mathrm{YP}$. In fact, bacterial counts decreased linearly in $\mathrm{Y}\left(\mathrm{Y}=-0.18 \mathrm{x}+8.27 ; \mathrm{r}^{2}=0.93\right)$ and $\mathrm{YUS}$ ( $\left.\mathrm{YUS}=-0.14 \mathrm{x}+0.37 ; \mathrm{r}^{2}=0.98\right)$.

From 14 to 28 days, the highest count of starter culture was recorded in probiotic yogurt (YP) and the viability was considerably stable and maintained during torage. At day 7, the number of counts increased by $2.8 \%$ in YPUS followed by a sharp decline at the 14th day. The presence of probiotic bacteria supported and helped growth of yogurt starter culture, even in the absence of sesame; this can be explained by a competition of starter culture with the probiotic for the nutritive elements by increase in the number of living cells. Significant enhancement of $L$. delbrueckiis ssp. bulgaricus counts was reported in yogurt made with a mixture of probiotic strains (Lactobacillus acidophilus, Bifidobacterium lactis and $L$. paracasei) (Donkor et al., 2006). An important increase (15-20\%) was observed in S. thermophilus counts during probiotic yogurts storage, but decreased after 21 day from 7 to 33\% (Dave and Shah, 1997). L. bulgaricus counts also increased initially then declined during the later stage. The population counts were similar for YPUSYPRS and YUS-YRS, without significant differences particularly at the beginning 
and end of storage indicating similar behavior of yogurt bacteria in the presence of raw or roasted ground sesame.

The viable counts of $B$. lactis $(\log \mathrm{cfu} / \mathrm{mL})$ during the four weeks cold storage (Figure 1b) was significantly $(P<0.001)$ affected by sesame supplementation and storage time. Except on day one, where the difference was insignificant. Probiotic supplemented yogurts with roasted or unroasted sesame exhibited higher $B$. lactis $(\mathrm{P}<0.05)$ counts compared to the control (YP) demonstrating its prebiotic potential. Probiotic count was within the 7.83 to $8.36 \mathrm{log} \mathrm{cfu} / \mathrm{mL}$ range in unsupplemented yogurt (YP) with optimum at day 1 and 7.73 to $8.44 \log \mathrm{cfu} / \mathrm{mL}$ in supplemented yogurt with an optimum at day 14 and 21 for YPUS and YPRS, respectively. The number of probiotic colonies varied between the supplemented yogurts (YPUS and YPRS); but difference on day 1 and 28 was not significant between them. Probiotic growth decreased initially for the first week for both supplemented yogurts, then increased in YPUS and remained stable until 21 day in YPRS. From day 1 to 28, in un-supplemented probiotic yogurt (YP) the number of viable count decreased linearly by $1 \log \mathrm{cfu} / \mathrm{mL}\left(\mathrm{YP}=-0.22 \mathrm{x}+8.56 ; \mathrm{r}^{2}=0.95\right)$. At 28 days, all sesame yogurts had significantly higher probiotic $(P<0.05)$ counts compared to the control by over $0.34 \log \mathrm{cfu} / \mathrm{mL}$.

Ground sesame (Sesamum indicum) addition promoted total bacterial organisms of B.animalis ssp lactis probably due to their improved survival by providing essential nutrients and oligosaccharides. Probiotic strains have nutritional requirement and important proteolytic activity to support their growth. For this, they need free amino acids to increase their viable cells (Vasiljevic and Shah, 2008). Indeed, proteins are the second predominant compounds in sesame seeds $(24 \mathrm{~g} / 100 \mathrm{~g})$ that is rich in methionine, cystine, arginine, and leucine $(36,25,140$, and $75 \mathrm{mg} / \mathrm{g}$ protein, respectively) (Namiki, 2007).

Sesame is an excellent source of essential amino acid significantly higher than that of FAO/WHO requirement for human except lysine (Johnson et al., 1979). The high (18-20\%) carbohydrate content of Sesamum indicum (11\% dietary fiber) with low glucose, fructose and starch and the presence of an oligo sugar planteose $O-\alpha-$ D-galactopyranosyl-(1,6)- $\beta$-D-fructofuranosyl- $\alpha$-D-glucopyranoside unaffected by the human digestive enzymes maybe responsible for the prebiotic potential of sesame (Namiki, 1995).

During storage, the viability of $B$. animalis in probiotic yogurts was superior to the minimum recommended level ( $>6 \mathrm{log} \mathrm{cfu} / \mathrm{g}$ ) to provide the beneficial health effects to the gut (Kongo et al., 2006). The viability loss/reduction in probiotic bacteria may be due to post-acidification during refrigerated storage (Sun and Griffiths, 2000). The co-culture of starter culture with bifidobacteria, which are a proteolytic species that is not recommended because they create acidic conditions (AbuTaraboush et al., 1998). Some probiotic strains are sensitive to antimicrobial substances produced by yogurt bacteria during refrigerated storage (Shah, 2001).

Our results showed that raw and roasted sesame may selectively impact probiotic growth with minimal effect on yogurt starter culture especially at the long cold storage (14-28 days). 

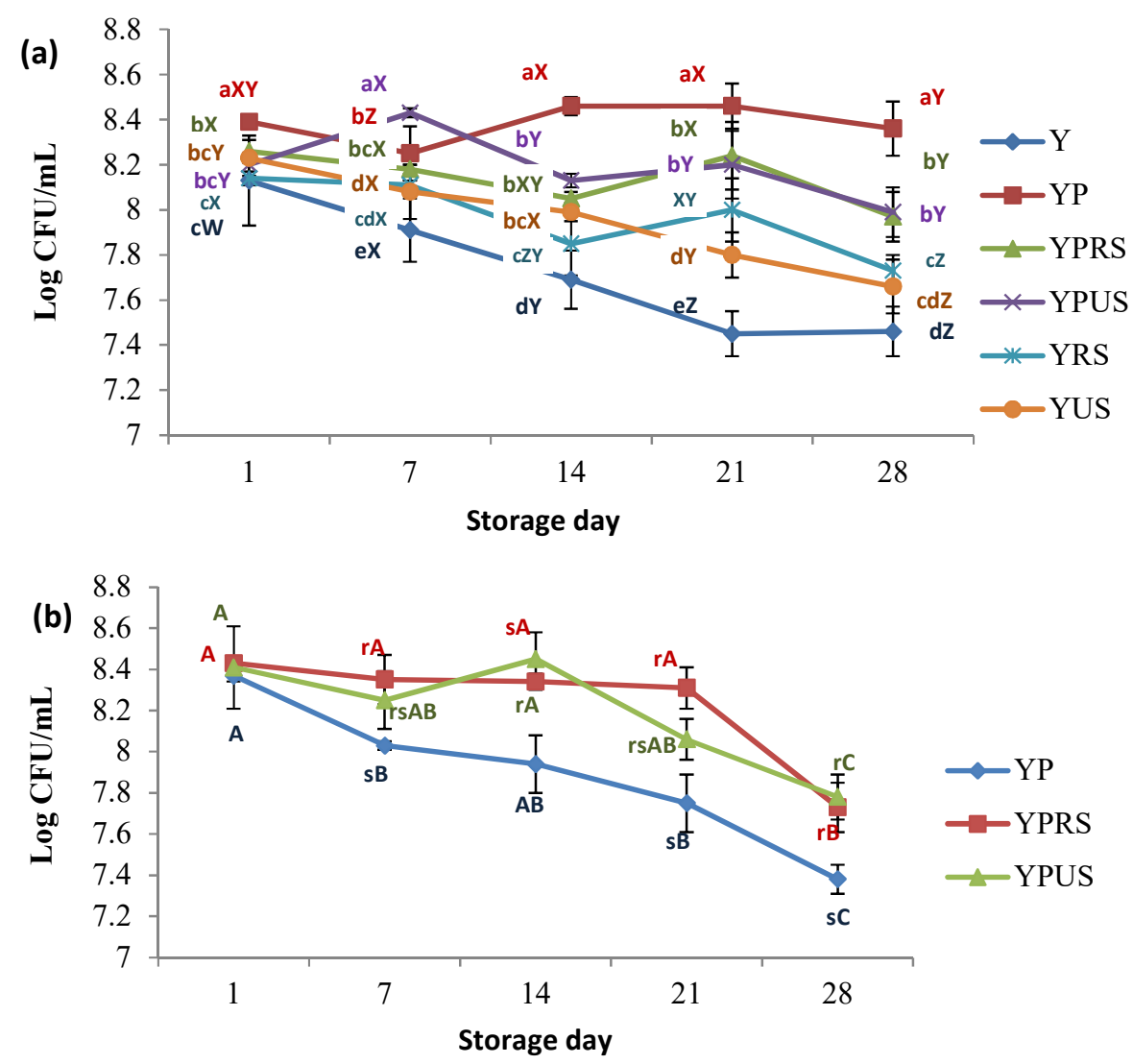

Figure 1. Bacterial viability of starter culture (a) and probiotic (b) in yogurts during 28 days storage at $4^{\circ} \mathrm{C}$. Means with different lower and upper case letters are significantly different $(P<0.05)$.

\section{Post-acidification (pH) and titratable acidity}

Yogurt $\mathrm{pH}$ were significantly affected by sesame supplementation $(P<0.0001)$ and storage time $(P<0.01)$. Yogurt bacteria metabolize carbohydrates for growth and energy producing various organic acids such as lactic, butyric, propionic, acetic and citric acids (Fernandez-Garcia and McGregor, 1994). $\mathrm{pH}$ is a measurement of hydrogen $\left(\mathrm{H}^{+}\right)$concentration contributed by the released organic acids during fermentation and storage. At day 1 , the $\mathrm{pH}$ among all yogurt treatments ranged from 4.41 to 4.52 (Figure 2a), then it decreased linearly until 3.68 to 3.91. There was no significant difference $(P>0.05)$ between unsupplemented yogurts ( $\mathrm{Y}$ an YP) during storage except on day 14 . From day 1 to 14 there were no differences 
between all supplemented yogurts with or without probiotic, indicating that probiotic had no effect on $\mathrm{pH}(P>0.05)$.
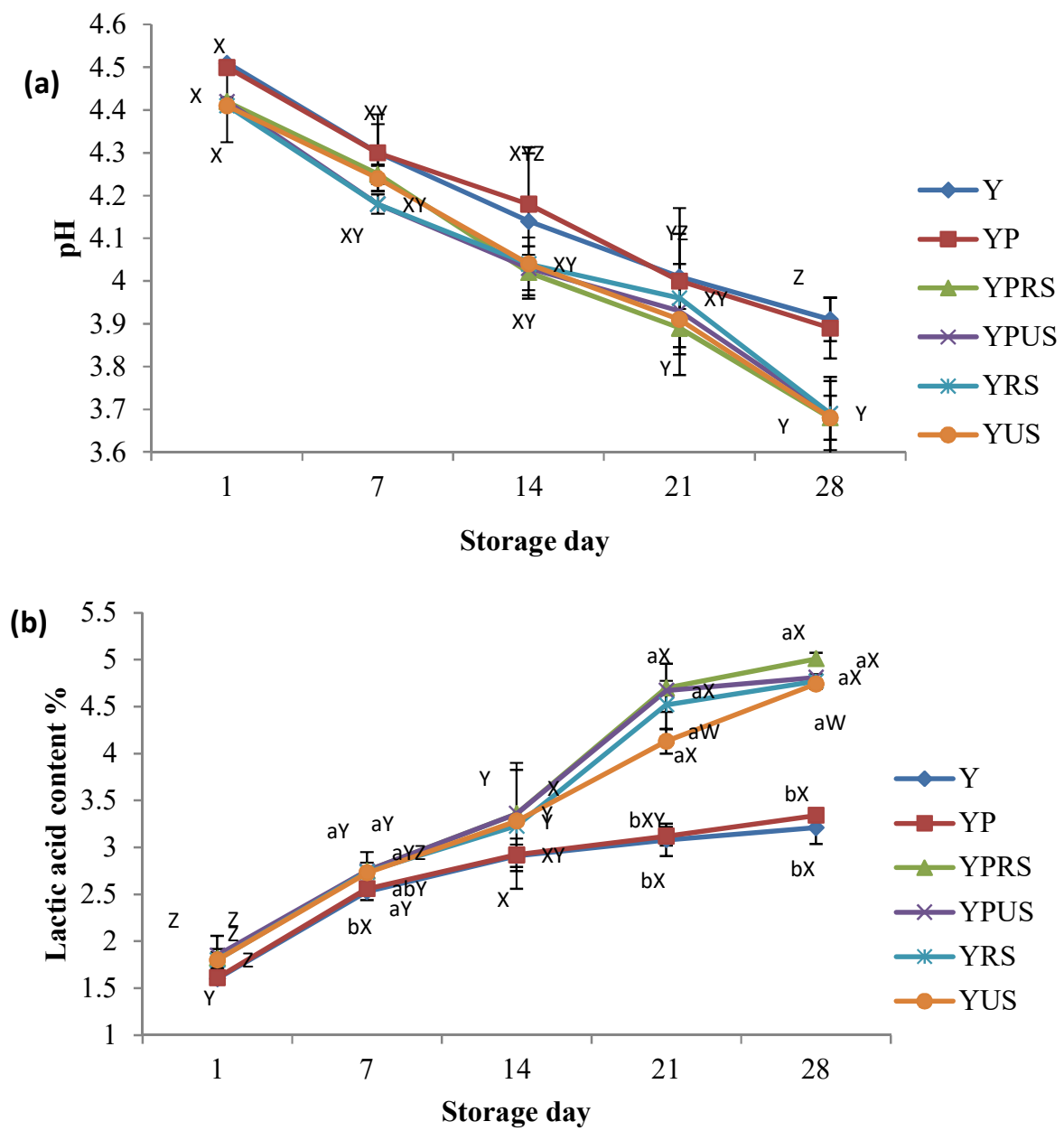

Figure 2. Post-acidification (a) and titratable acidity (b) in yogurts during 28 days of storage at $4{ }^{\circ} \mathrm{C}$. Means with different lower and upper case letter are significantly different $(\mathrm{P}<0.05)$.

TTA measurement is an indicator of bacterial metabolic activity in fermented dairy product. At day 1 the TTA values ranged between 1.6 and 1.85 then increased until 3.21 and 5 (Figure 2b). TTA for the four sesame yogurts was higher than that of control and probiotic yogurts (Y and YP) during storage; the evolution of titratable acidity in those yogurts (YUS, YRS, YPUS, YPRS) may be described in two distinct phases. Between day 1 and 14, there was a gradual significant increase and between day 14 and 28 the rate of increase was greater and rapid 
(YUS $=0.27 \mathrm{x}+1.15 ; \mathrm{r}^{2}=0.99 ;$ YPRS $\left.=0.83 \mathrm{x}+1.02 ; \mathrm{r}^{2}=0.97\right)$. The addition of both raw and roasted ground sesame was helpful in increasing total titratable acidity $(P<$ 0.01 ) during storing indicating that microorganisms were more active in the presence of sesame seeds. Sesame contains various carbohydrates including Dglucose $(3.63 \%)$, D-fructose $(3.43 \%)$, D-galactose $(0.40 \%)$, sucrose $(0.17 \%)$, raffinose $(0.59 \%)$, stachyose $(0.38 \%)$, planteose $(0.23 \%)$, and sesamose $(0.14 \%)$ which may easily be available and metabolized by yogurt bacteria (Wankhede and Tharanathan, 1976). The reduction of $\mathrm{pH}$ and liberation of lactic acids reflects the high metabolic activity of yogurt bacteria. Lactic acid bacteria (LAB) used milk proteins (nitrogen source) and carbohydrate from sesame seeds (carbon source) to produce organic acids and other volatile compounds including acetaldehyde and diacetyl. Organic acids play an important role as natural preservatives and the volatile compounds contribute to the organoleptic properties and yogurt flavor (Fernandez-Garcia and McGregor, 1994).

\section{Proteolysis by o-phthalaldehyde (OPA) assay}

Proteolytic activity improved significantly $(P<0.05)$ in the presence of probiotic and sesame seeds (Table 2). All yogurts had higher OPA values (0.9-1.04) than that of the control yogurt $(0.62)$ at the beginning and during refrigerated storage. The highest proteolytic activity (1.26) was recorded in both supplemented yogurts (YRS and YUS) at days 14 and 21, respectively. Proteolytic activity of bacteria was similar in probiotic sesame containing yogurt (YPUS and YPRS) indicating that seed roasting had no effect on yogurt proteolysis. Proteolysis increased in all yogurts until the optimum absorbance recorded on day 14 or 21 depending on yogurt sample then decreased at the end of storage.

Table 2.Proteolysis (OPA) of yogurts during 28 days storage at $4{ }^{\circ} \mathrm{C}$

\begin{tabular}{cccccc}
\hline \multicolumn{5}{c}{ Storage time (Days) } \\
\hline Sample & $\mathbf{1}$ & $\mathbf{7}$ & $\mathbf{1 4}$ & $\mathbf{2 1}$ & $\mathbf{2 8}$ \\
\hline Y & $0.62 \pm 0.01^{\mathrm{cZ}}$ & $0.78 \pm 0.02^{\mathrm{cXY}}$ & $0.85 \pm 0.02^{\mathrm{dXY}}$ & $0.87 \pm 0.01^{\mathrm{dX}}$ & $0.74 \pm 0.03^{\mathrm{cY}}$ \\
YP & $0.90 \pm 0.01^{\mathrm{bY}}$ & $0.99 \pm 0.06^{\mathrm{bXY}}$ & $1.12 \pm 0.02^{\mathrm{cX}}$ & $1.04 \pm 0.03^{\mathrm{cXY}}$ & $0.99 \pm 0.04^{\mathrm{bXY}}$ \\
YPRS & $1.01 \pm 0.02^{\mathrm{abZ}}$ & $1.13 \mathrm{ab} \pm 0.04^{\mathrm{XYZ}}$ & $1.25 \pm 0.06^{\mathrm{abX}}$ & $1.07 \pm 0.08^{\mathrm{bcYZ}}$ & $1.14 \pm 0.02^{\mathrm{aXY}}$ \\
YPUS & $1.04 \pm 0.04^{\mathrm{aZ}}$ & $1.17 \pm 0.06^{\mathrm{aXY}}$ & $1.22 \pm 0.01^{\mathrm{abX}}$ & $1.08 \mathrm{~b} \pm 0.03^{\mathrm{cYZ}}$ & $1.08 \pm 0.08^{\mathrm{abYZ}}$ \\
YRS & $0.93 \pm 0.01^{\mathrm{abY}}$ & $1.19 \pm 0.02^{\mathrm{aX}}$ & $1.27 \pm 0.05^{\mathrm{aX}}$ & $1.17 \pm 0.03^{\mathrm{abX}}$ & $1.16 \pm 0.07^{\mathrm{aX}}$ \\
YUS & $0.98 \pm 0.03^{\mathrm{abZ}}$ & $1.06 \pm 0.02^{\mathrm{abYZ}}$ & $1.18 \pm 0.06^{\mathrm{bcXY}}$ & $1.26 \pm 0.02^{\mathrm{aX}}$ & $1.14 \pm 0.01^{\mathrm{aXY}}$ \\
\hline
\end{tabular}

Results are expressed as absorbance at $340 \mathrm{~nm}$; means with different lower and upper case letters in the same column or row are significantly different $(P<0.05)$.

Enhanced proteolytic activity suggests that enzymatic activity of protease from starter culture and probiotic was markedly improved in the presence of ground sesame seeds that provided divalent ions including $\mathrm{Ca}^{2+}, \mathrm{Fe}^{2+}$ and $\mathrm{Mg}^{2+}$. Those minerals were reported to be necessary for protease activity (Llorente-Bousquets et al., 2008). Indeed, sesame seed was found to be rich in various minerals. Among them, calcium and iron, which are often deficient in modern diets, and present in high concentrations (1200 and $9.6 \mathrm{mg} / 100 \mathrm{~g}$, respectively) (Namiki, 2007). 


\section{Syneresis}

Syneresis is an undesirable feature in yogurt resulting from the separation of liquid phase (serum) from the protein gel (Shah, 2003). Syneresis of investigated yogurts was significantly affected by sesame supplementation $(P<0.001)$ and storage time $(P<0.001)$ but there was no difference between roasted and unroasted sesame supplementation $(P>0.05)$. At day 1 , syneresis varied between 41.63 and $42.26 \%$ (Table 3$)$ in all yogurts without significant difference $(P>0.05)$. Whey separation of sesame containing yogurt except YPUS followed parallel biphasic trends during storage with inflection at 14 days. From day 1 to 14 , differences in level of syneresis were insignificant among the three supplemented yogurts (YUS, YRS, YPRS) and between control (Y) and probiotic yogurt (YP). Storage linearly increased whey separation (14-28 days) especially in supplemented yogurts $\left(\mathrm{YUS}=2.63 \mathrm{x}+41.8 ; \quad \mathrm{r}^{2}=0.96 ; \quad\right.$ YRS $=3.33 \mathrm{x}+40.6 ; \quad \mathrm{r}^{2}=0.98, \quad$ YPRS $=2.5 \mathrm{x}+41.33$; $\left.\mathrm{r}^{2}=0.99\right)$.

Syneresis increased with sesame addition compared to control and probiotic yogurts (Table 3 ). Many studies have reported higher syneresis accompanied with low viscosity for enriched yogurts with various plant ingredients. Therefore, addition of fruits decreased water-holding capacity of protein and viscosity resulting in increased syneresis (Akyüz and Coflkun, 1995; Mohamed et al., 2014; Zainoldin and Baba, 2009). At the end of cold storage, control and probiotic yogurts ( $\mathrm{Y}$ and $\mathrm{YP}$ ) displayed the lowest syneresis (45.7and $44.03 \%$, respectively) whereas the highest mean value $(50.36 \%)$ was recorded in roasted sesame containing yogurt (YRS). The syneresis trend of these yogurts paralleled changes in their proteolysis (OPA) and TTA, thereby indicating their strong association. Therefore, increased syneresis in sesame containing yogurts can be attributed to lactic acid bacteria degradation of milk proteins that are responsible for water retention.

Table 3. Syneresis of yogurts during 28 days storage at $4^{\circ} \mathrm{C}$

\begin{tabular}{cccccc}
\hline \multicolumn{5}{c}{ Storage time (Days) } \\
\hline Sample & $\mathbf{1}$ & $\mathbf{7}$ & $\mathbf{1 4}$ & $\mathbf{2 1}$ & $\mathbf{2 8}$ \\
\hline Y & $41.63 \pm 3.12^{\mathrm{Z}}$ & $40.93 \pm 1.16^{\mathrm{cZ}}$ & $42 \pm 2.39^{\mathrm{bZ}}$ & $43.30 \pm 1.18^{\mathrm{cY}}$ & $45.70 \pm 3.31^{\mathrm{bcX}}$ \\
YP & $42.03 \pm 2.31^{\mathrm{Y}}$ & $41.60 \pm 0.4^{\mathrm{bcY}}$ & $42.63 \pm 4.41^{\mathrm{abY}}$ & $44.00 \pm 1.31^{\mathrm{bcX}}$ & $44.03 \pm 3.34^{\mathrm{cX}}$ \\
YPRS & $41.90 \pm 1.86^{\mathrm{Z}}$ & $43.33 \pm 1.13^{\mathrm{a} Y Z}$ & $43.87 \pm 0.64^{\mathrm{abWZ}}$ & $46.27 \pm 2.91^{\mathrm{abXY}}$ & $48.87 \pm 0.56^{\mathrm{abX}}$ \\
YPUS & $41.7 \pm 2.45^{\mathrm{Y}}$ & $41.53 \pm 3.81^{\mathrm{bcY}}$ & $42.60 \pm 0.88^{\mathrm{abY}}$ & $43.20 \pm 2.81^{\mathrm{cY}}$ & $48.17 \pm 2.76^{\mathrm{abX}}$ \\
YRS & $41.83 \pm 3.78^{\mathrm{Z}}$ & $42.90 \pm 2.56^{\mathrm{abZ}}$ & $43.70 \pm 2.98^{\mathrm{abZ}}$ & $47.77 \pm 3.14^{\mathrm{aY}}$ & $50.37 \pm 0.97^{\mathrm{aX}}$ \\
YUS & $42.27 \pm 1.75^{\mathrm{Z}}$ & $42.97 \pm 2.84^{\mathrm{abYZ}}$ & $44.30 \pm 1.16^{\mathrm{aY}}$ & $46.10 \mathrm{a} \pm 1.32^{\mathrm{bX}}$ & $49.57 \pm 4.54^{\mathrm{aW}}$ \\
\hline
\end{tabular}

Results are expressed in \% of collected whey; means with different lower and upper case letters in the same column or row are significantly different $(P<0.05)$.

\section{Antioxidant activity}

Yogurts containing raw or roasted sesame displayed strong scavenging capacity, whereas control and probiotic yogurts ( $\mathrm{Y}$ and $\mathrm{YP}$ ) manifested lower scavenging 
capacity (Figure3). Our results agreed with those of Hashish et al (2014) where the antioxidant activity of yogurt increased with white and red sesame tahina (1 to 6\%) supplementation. Many studies reported higher antioxidant capacity of yogurt supplemented with various ingredients from plant material (fruits, leaves and seeds) compared to their control (Muniandy et al., 2016; Sah et al., 2016; Van Nieuwenhove et al., 2019). This potential was attributed to the content of phenolic compounds (Baba et al., 2014). In our study, proteolysis was more marked in yogurts enriched with sesame seeds. In addition, bioactive peptides released by lactic acid bacteria during proteolysis may play an important role as antioxidant compound.

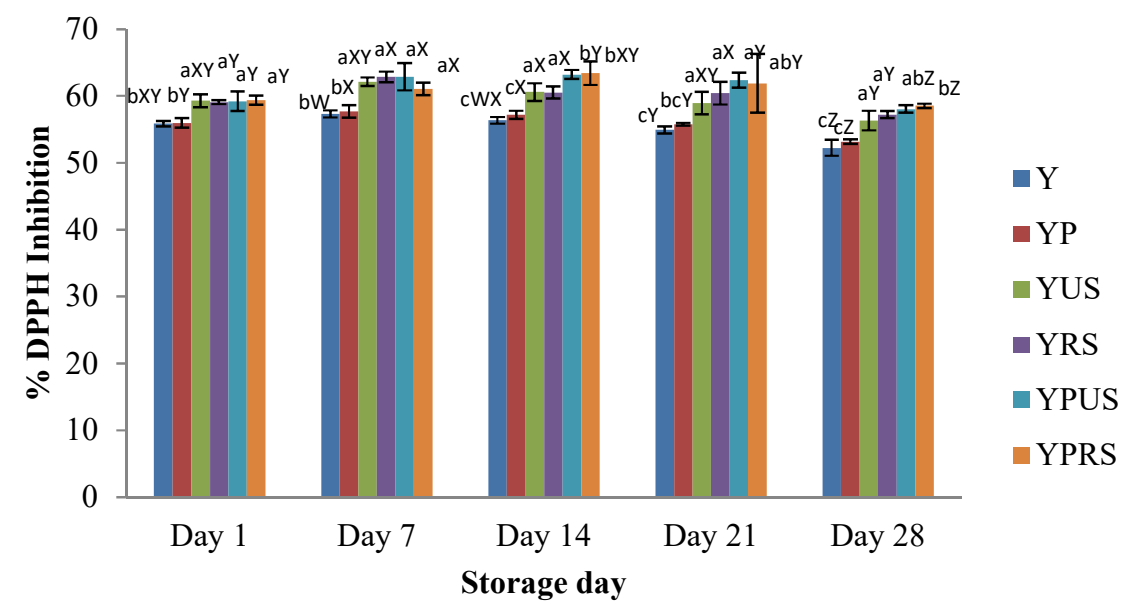

Figure 3. DPPH radical scavenging activity of yogurts during 28 days storage at $4{ }^{\circ} \mathrm{C}$. Means with different lower and upper case letters are significantly different $(P<0.05)$.

\section{Sensory analysis}

The results of the sensory evaluation after 1 day of refrigerated storage performed in all yogurt samples are reported in Figure 4. Roasted sesame containing yogurts (YRS and YPRS) were preferred by the panelists in color, flavor, taste and sweetness. Sweetness was enhanced with roasted seeds that contained more sugar; whereas taste and flavor was improved with roasting that enhances the pleasant characteristic flavor of hazelnut (Namiki, 2007).

Color is the first characteristic perceived by consumer and the major attribute in food industry. Color of roasted sesame containing yogurts (YRS and YPRS) was preferred due to the pigmentation caused by browning substances released from the Maillard reaction that gave better visual appearance to the product.

Control yogurt $(\mathrm{Y})$ showed the better score for both texture and acidity. This implies that the high acidity of the supplemented yogurt was perceived by the panelists. Because no differences were observed, probiotic roasted sesame yogurt 
(YPRS) and roasted sesame yogurt (YRS) were equally accepted $(P>0.05)$ at first view indicating that probiotic had no effect on sensory attributes of yogurt. The same results were observed when comparing some sensory characteristics (appearance, flavor, texture) between standard and probiotic yogurt made with $L$. rhamnosus GR-1 and L .reuteri RC-14 (Hekmat and Reid, 2006).
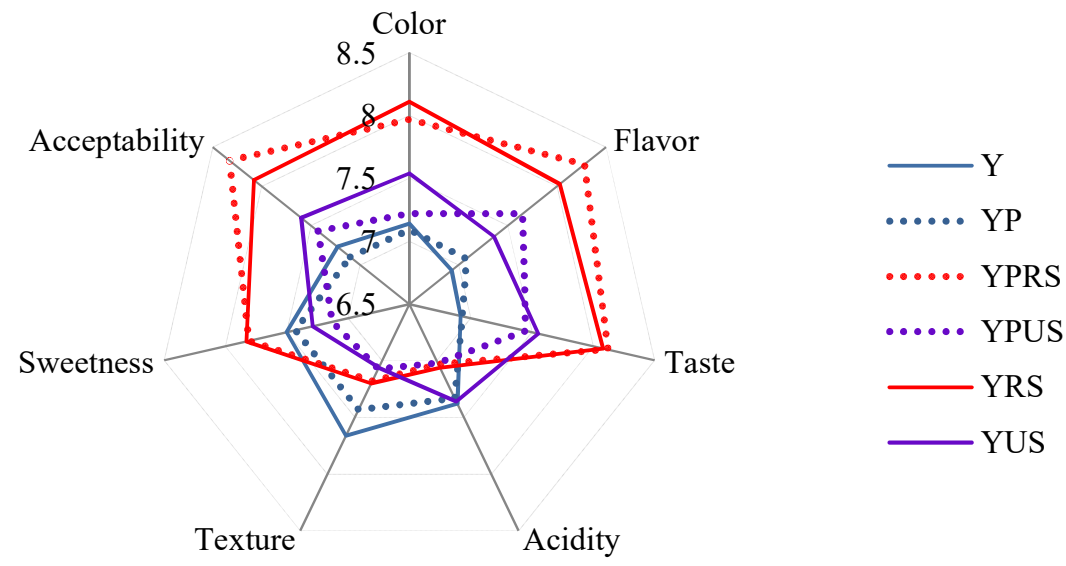

Figure 4. Diagram of sample scores of the sensory evaluation of probiotic stirred sesame yogurt.

\section{Conclusion}

In this study, ground (raw or roasted) sesame yogurt supplementation (6\%) selectively stimulated bifidogenic microbial growth, increased syneresis, acid production and proteolysis and reduced $\mathrm{pH}$. Antioxidant activity of yogurts also increased in the presence of sesame during storage. The enhanced antioxidant potential and sensory properties of roasted sesame supplemented yogurts can be beneficial to improve human health and consumer's acceptability; this implies that addition of roasted sesame in yogurt manufacture can be recommended without adverse effect on the properties of this product knowing that it provides selective conditions for probiotic growth.

\section{References}

Abu-Taraboush, H., Al-Dagal, M., Al-Royli, M., 1998. Growth, viability, and proteolytic activity of Bifidobacteria in whole camel milk. Journal of Dairy Science, 81, 354-361.

Agil, R., Gaget, A., Gliwa, J., Avis, T.J., Willmore, W.G., Hosseinian, F., 2013. Lentils enhance probiotic growth in yogurt and provide added benefit of antioxidant protection. LWT-Food Science and Technology, 50, 45-49. 
Akalın, A., Unal, G., Dinkci, N., Hayaloglu, A., 2012. Microstructural, textural, and sensory characteristics of probiotic yogurts fortified with sodium calcium caseinate or whey protein concentrate. Journal of Dairy Science, 95, 3617-3628.

Akyüz, N., Coflkun, H., 1995. Production of fruit yogurt in yogurt. National Productivity Center, Mert Pres, 285-294.

Alexandre, Y., Le Blay, G., Boisramé-Gastrin, S., Le Gall, F., Héry-Arnaud, G., Gouriou, S., Vallet, S., Le Berre, R., 2014. Probiotics: a new way to fight bacterial pulmonary infections? Médecine et maladies infectieuses, 44, 9-17.

Allgeyer, L., Miller, M.J., Lee, S.-Y., 2010. Sensory and microbiological quality of yogurt drinks with prebiotics and probiotics. Journal of Dairy Science, 93, 4471-4479.

Amirdivani, S., Baba, A.S., 2011. Changes in yogurt fermentation characteristics, and antioxidant potential and in vitro inhibition of angiotensin-1 converting enzyme upon the inclusion of peppermint, dill and basil. LWT-Food Science and Technology, 44, 1458-1464.

Anilakumar, K.R., Pal, A., Khanum, F., Bawa, A.S., 2010. Nutritional, medicinal and industrial uses of sesame (Sesamum indicum L.) seeds-an overview. Agriculturae Conspectus Scientificus, 75, 159-168.

Anukam, K.C., Reid, G., 2007. Probiotics: 100 years (1907-2007) after Elie Metchnikoff's observation. Communicating current research and educational topics and trends in applied microbiology, 1, 466-474.

Aprianita, A., Purwandari, U., Watson, B., Vasiljevic, T., 2009. Physico-chemical properties of flours and starches from selected commercial tubers available in Australia. International Food Research Journal, 16, 507-520.

Aziz, A.H., Aboeleinen, K.A., 2010. Use of Sesame and probiotic lactobacili in making nutraceutical fermented dairy products. Journal of Food and Dairy Sciences, 1, 555565.

Baba, A., Najarian, A., Shori, A., Lit, K., Keng, G., 2014. In vitro inhibition of key enzymes related to diabetes and hypertension in Lycium barbarum-yogurt. Arabian Journal of Science and Engineering, 39, 5355-5362.

Bae, J.-J., Yeon, S.-J., Park, W.-J., Hong, G.-E., Lee, C.-H., 2016. Production of sesaminol and antioxidative activity of fermented sesame with Lactobacillus plantarum P8, Lactobacillus acidophilus ATCC 4356, Streptococcus thermophilus S10. Food Science and Biotechnology, 25, 199-204.

Bedigian, D., 2004. History and lore of sesame in Southwest Asia. Economic botany, 58, 329-353.

Behrad, S., Yusof, M., Goh, K., Baba, A., 2009. Manipulation of probiotics fermentation of yogurt by cinnamon and licorice: effects on yogurt formation and inhibition of Helicobacter pylori growth in vitro. World Academy of Science, Engineering and Technology, 60, 590-594.

Bernat, N., Cháfer, M., Chiralt, A., González-Martínez, C., 2015. Development of a nondairy probiotic fermented product based on almond milk and inulin. Food Science and Technology International, 21, 440-453.

Dave, R.I., Shah, N.P., 1997. Viability of yoghurt and probiotic bacteria in yoghurts made from commercial starter cultures. International Dairy Journal, 7, 31-41. 
Donkor, O., Henriksson, A., Vasiljevic, T., Shah, N., 2006. Effect of acidification on the activity of probiotics in yoghurt during cold storage. International Dairy Journal, 16, 1181-1189.

Donkor, O.N., Nilmini, S., Stolic, P., Vasiljevic, T., Shah, N., 2007. Survival and activity of selected probiotic organisms in set-type yoghurt during cold storage. International Dairy Journal, 17, 657-665.

Espírito Santo, A.P.d., Silva, R., Soares, F., Anjos, D., Gioielli, L.A., Oliveira, M.N.D., 2010. Super fruit may boost shelf-life for probiotic yoghurt [Depoimento a Stephen Daniells]. Food Quality News, 16.

Fernandez-Garcia, E., McGregor, J.U., 1994. Determination of organic acids during the fermentation and cold storage of yogurt. Journal of Dairy Science, 77, 2934-2939.

Garrigues, C., Johansen, E., Pedersen, M.B., 2010. Complete genome sequence of Bifidobacterium animalis subsp. lactis BB-12, a widely consumed probiotic strain. Journal of Bacteriology, 192, 2467-2468.

Gibson, G.R., Roberfroid, M.B., 1995. Dietary modulation of the human colonic microbiota: introducing the concept of prebiotics. The Journal of Nutrition, 125, 14011412.

Gilliland, S., Walker, D., 1990. Factors to consider when selecting a culture of Lactobacillus acidophilus as a dietary adjunct to produce a hypocholesterolemic effect in humans. Journal of Dairy Science, 73, 905-911.

Halvorsen, B.L., Holte, K., Myhrstad, M.C., Barikmo, I., Hvattum, E., Remberg, S.F., Wold, A.-B., Haffner, K., Baugerød, H., Andersen, L.F., 2002. A systematic screening of total antioxidants in dietary plants. The Journal of Nutrition, 132, 461-471.

Haque, Z., Ji, T., 2003. Cheddar whey processing and source: II. Effect on non-fat ice cream and yoghurt 1. International Journal of Food Science \& Technology, 38, 463473.

Haschke, F., Wang, W., Ping, G., Varavithya, W., Podhipak, A., Rochat, F., Link-Amster, H., Pfeifer, A., Diallo-Ginstl, E., Steenhout, P., 1998. Clinical trials prove the safety and efficacy of the probiotic strain Bifidobacterium Bb12 in follow-up formula and growing-up milks. Monatsschrift Kinderheilkunde, 146, S26-S30.

Hatcher, G.E., Lambrecht, R.S., 1993. Augmentation of macrophage phagocytic activity by cell-free extracts of selected lactic acid-producing bacteria. Journal of Dairy Science, 76, 2485-2492.

Hekmat, S., Reid, G., 2006. Sensory properties of probiotic yogurt is comparable to standard yogurt. Nutrition Research, 26, 163-166.

Heller, K.J., 2001. Probiotic bacteria in fermented foods: product characteristics and starter organisms. The American Journal of Clinical Nutrition, 73, 374s-379s.

Johnson, L., Suleiman, T., Lusas, E., 1979. Sesame protein: A review and prospectus. Journal of the American Oil Chemists' Society, 56, 463-468.

Kailasapathy, K., Harmstorf, I., Phillips, M., 2008. Survival of Lactobacillus acidophilus and Bifidobacterium animalis ssp. lactis in stirred fruit yogurts. LWT-Food Science and Technology, 41, 1317-1322.

Kinsella, J.E., Damodaran, S., German, B., 1985. Physicochemical and functional properties of oilseed proteins with emphasis on soy proteins. New protein foods, (USA). 
Kongo, J., Gomes, A., Malcata, F.X., 2006. Manufacturing of fermented goat milk with a mixed starter culture of Bifidobacterium animalis and Lactobacillus acidophilus in a controlled bioreactor. Letters in Applied microbiology, 42, 595-599.

Llorente-Bousquets, A., Pérez-Munguía, S., Farrés, A., 2008. Novel extracellular proteolytic activity in Pediococcus acidilactici ATCC 8042. Canadian Journal of Microbiology, 54, 694-699.

Mckinley, M.C., 2005. The nutrition and health benefits of yoghurt. International Journal of Dairy Technology, 58, 1-12.

Mohamed, A., Zayan, A.F., Shahein, N., 2014. Physiochemical and sensory evaluation of yoghurt fortified with dietary fiber and phenolic compounds. Life Science Journal, 11, 816-822.

Moller, C., De Vrese, M., 2004. Probiotic effects of selected acid bacteria. Milchwissenschaft, 59, 597-601.

Muniandy, P., Shori, A.B., Baba, A.S., 2016. Influence of green, white and black tea addition on the antioxidant activity of probiotic yogurt during refrigerated storage. Food Packaging and Shelf Life, 8, 1-8.

Namiki, M., 1995. The chemistry and physiological functions of sesame. Food Reviews International, 11, 281-329.

Namiki, M., 2007. Nutraceutical functions of sesame: a review. Critical Reviews in Food Science and Nutrition, 47, 651-673.

Plessas, S., Bosnea, L., Alexopoulos, A., Bezirtzoglou, E., 2012. Potential effects of probiotics in cheese and yogurt production: A review. Engineering in Life Sciences, 12, 433-440.

Reddy, G., Friend, B., Shahani, K., Farmer, R., 1983. Antitumor activity of yogurt components. Journal of Food Protection, 46, 8-11.

Rodrigues, D., Rocha-Santos, T.A., Gomes, A.M., Goodfellow, B.J., Freitas, A.C., 2012. Lipolysis in probiotic and synbiotic cheese: The influence of probiotic bacteria, prebiotic compounds and ripening time on free fatty acid profiles. Food Chemistry, 131, 1414-1421.

Rybka, S., Kailasapathy, K., 1995. The survival of culture bacteria in fresh and freeze-dried AB yoghurts. Australian Journal of Dairy Technology, 50, 51.

Sah, B., Vasiljevic, T., McKechnie, S., Donkor, O., 2016. Effect of pineapple waste powder on probiotic growth, antioxidant and antimutagenic activities of yogurt. Journal of Food Science and Technology, 53, 1698-1708.

Salunke, D., Chavan, J., Adsule, R., Kadam, S., 1992. World oil seeds: Chemistry, technology and utilization pp. 170-173. AVI publishers, New York.

Shah, N., 2001. Contagious divides: Epidemics and race in San Francisco's Chinatown. Univ. of California Press.

Shah, N., 2003. Yogurt | The Product and its Manufacture. In: Encyclopedia of Food Sciences and Nutrition, Second Edition, Caballero B. Ed., p. 6252-6259. Academic Press

Shah, N.P., 2007. Functional cultures and health benefits. International Dairy Journal, 17, 1262-1277.

Sodini, I., Remeuf, F., Haddad, S., Corrieu, G., 2004. The relative effect of milk base, starter, and process on yogurt texture: a review. Critical Reviews in Food Science and Nutrition, 44, 113-137. 
Sun-Waterhouse, D., Zhou, J., Wadhwa, S.S., 2013. Drinking yoghurts with berry polyphenols added before and after fermentation. Food Control, 32, 450-460.

Sun, W., Griffiths, M.W., 2000. Survival of bifidobacteria in yogurt and simulated gastric juice following immobilization in gellan-xanthan beads. International Journal of Food Microbiology, 61, 17-25.

Tamime, A., Saarela, M., Sondergaard, A.K., Mistry, V., Shah, N., 2005. Production and maintenance of viability of probiotic microorganisms in dairy products. Probiotic Dairy Products, 39-72.

Uzun, B., Arslan, C., Karhan, M., Toker, C., 2007. Fat and fatty acids of white lupin (Lupinus albus L.) in comparison to sesame (Sesamum indicum L.). Food Chemistry, 102, 45-49.

Van Nieuwenhove, C.P., Moyano, A., Castro-Gómez, P., Fontecha, J., Sáez, G., Zárate, G., Pizarro, P.L., 2019. Comparative study of pomegranate and jacaranda seeds as functional components for the conjugated linolenic acid enrichment of yogurt. LWTFood Science and Technology, 111, 401-407.

Vasiljevic, T., Shah, N.P., 2008. Probiotics-from Metchnikoff to bioactives. International Dairy Journal, 18, 714-728.

Viljoen, B.C., 2001. The interaction between yeasts and bacteria in dairy environments. International Journal of Food Microbiology, 69, 37-44.

Wankhede, D.B., Tharanathan, R.N., 1976. Sesame (Sesamum indicum) carbohydrates. Journal of Agricultural and Food Chemistry, 24, 655-659.

Zainoldin, K., Baba, A., 2009. The effect of Hylocereus polyrhizus and Hylocereus undatus on physicochemical, proteolysis, and antioxidant activity in yogurt. World Academy of Science, Engineering and Technology, 60, 361-366. 